\title{
CHARACTERIZATION OF FUSION PRODUCTS FROM PROTOPLASTS OF YEASTS AND THEIR SEGREGANTS BY ELECTROPHORETIC KARYOTYPING AND RAPD
}

\author{
Cleide Viviane Buzanello Martins ${ }^{1}$, Jorge Horii ${ }^{*}$, Aline Aparecida Pizzirani-Kleiner ${ }^{2}$ \\ ${ }^{1}$ Departamento de Ciência e Tecnologia Agroindustrial and ${ }^{2}$ Departamento de Genética da Escola Superior \\ de Agricultura "Luiz de Queiroz", Universidade de São Paulo, Piracicaba, SP, Brasil. \\ Submitted: May 06, 1998; Returned to authors for corrections: August 17, 1998; Approved: November 12, 1998.
}

\begin{abstract}
In order to characterize fusion products from yeast protoplasts and their segregants, with important features to the wine making industry, electrophoretic karyotyping and RAPD (Random Amplified Polymorphic DNA) were utilized. Electrophoretic karyotyping was performed by the CHEF ("contour-clamped homogeneous electric field electrophoresis") method, which allowed the detection of chromosomal band complementation in fusion products and the presence of patterns of both parental and intermediary strains in segregants. By utilizing two primers, an amplification pattern of DNA fragments was obtained. While fusion products (diploid) showed a pattern of complementary bands, segregants showed bands of either parental strains or even intermediary bands.
\end{abstract}

Key words: Protoplast fusion, electrophoretic karyotyping, RAPD.

\section{INTRODUCTION}

Industries, especially those that make use of yeasts in the production of alcoholic drinks, are very traditional, reflecting the conservative attitude that men, in general, have towards the nature of the food and beverage they produce. Besides that, industries of alcoholic drinks have shown recent innovations by introducing benefits from reengineering and genetic manipulation. Beer and wine making industries have faced many challenges over the past years, such as, improving yeast resistance to ethanol, temperature and carbon dioxide as well as eliminating or diminishing the production of compounds which interfere with the quality of beer and wine.

In order to obtain strains showing more suitable properties, genetic manipulation methods have been used. However, due to the aneuploid, diploid or polyploid nature of most strains used in beer and wine making, traditional crossing techniques have not been very successful. Thus, the use of new technologies was necessary, such as protoplast fusion and transformation. New genotypes were obtained by protoplast fusion, which showed recombinant features, while the transformed strains showed heterologous genes $(17,7,13)$.

Other applications of genetic techniques are the identification, characterization and monitoring of strains used in the production of alcoholic drinks by electrophoretic karyotyping $(10,2,20,18,4)$ and RAPD (Random Amplified Polymorphic DNA) markers (5).

Yeasts used for producing non-distilled drinks need additional properties, such as low levels of $\mathrm{H}_{2} \mathrm{~S}$

\footnotetext{
* Corresponding author. Mailing address: Departamento de Ciência e Tecnologia Agroindustrial, ESALQ/USP, Av. Pádua Dias, 11, CEP 13418-900, Piracicaba, SP, Brasil. FAX (+5519) 429-4275
} 
production $(16,7) . \mathrm{H}_{2} \mathrm{~S}$ is an undesired malodorous compound which seriously depreciates beer and wine quality (21). Flocculation, another interesting feature in strains used by beer and wine making industries, has recently been introduced by genetic changes in these microorganisms (19). This phenomenon has been detected in some yeast strains, which, under certain circumstances, tend to cluster and form flakes, which are deposited on the bottom of the fermenter.

The objective of this paper is, therefore, to genetically characterize parental strains used in protoplast fusion, fusion products (FP) and their segregants (S) by means of electrophoretic karyotyping and RAPD markers.

\section{MATERIALS AND METHODS}

Biological Material: for this study, two yeast strains (Saccharomyces cerevisiae) and hybrids obtained from protoplast fusion of these two strains and their recombinants were used. The strain identified as IZ 987, unable to produce $\mathrm{H}_{2} \mathrm{~S}$, was provided by the laboratory at the Departamento de Ciência e Tecnologia Agroindustrial (Department of Agroindustrial Science and Technology) at the Escola Superior de Agricultura "Luiz de Queiroz" ("Luiz de Queiroz" Agriculture School) /USP (University of São Paulo). The other, ABXR 11B, highly flocculent, was provided by the Laboratorio de Genética de Leveduras do Departamento de Genética da Escola Superior de Agricultura "Luiz de Queiroz" (Yeast Genetic Laboratory, Department of Genetics, "Luiz de Queiroz “ Agriculture School)/ USP (University of São Paulo).

Pulsed-field Electrophoresis for yeast chromosomal DNA separation: strains were incubated in Erlenmeyer flasks with $100 \mathrm{ml}$ YEPD ( $2 \%$ glucose, $2 \%$ peptone, $1 \%$ yeast extract), at $28^{\circ} \mathrm{C}$ under constant agitation (150 rpm), to half-grown phase. Samples were harvested by centrifugation (10 minutes at $5000 \mathrm{~g}$ ) and washed three times with 0.05 $\mathrm{M}$ EDTA, $\mathrm{pH}$ 8.0. After washing, the cells were resuspended at a concentration of approximately $5 \times 10^{9}$ cells $/ \mathrm{ml}$ in EDTA (1). Cell suspension was heated at $42^{\circ} \mathrm{C}$, and, then, combined with $1.4 \%$ LGT (low gelling temperature) agarose (1:1 solution), and immediately transferred into plug moulds. For plugs solidification, moulds were refrigerated. After gel solidification, the plugs were transferred (with spatula) into tubes containing NDS (0.5 M EDTA, $\mathrm{pH}$ 5.8/ $10 \mathrm{mM}$ Tris-HCl, $\mathrm{pH}$ 9.5/ Sodium NlauroyLsarcosinate), proteinase $\mathrm{K}(1 \mathrm{mg} / \mathrm{ml})$ and incubated at $50^{\circ} \mathrm{C}$ for approximately 15 hours (9).

Following incubation, the plugs were washed four times, the first three times with $0.05 \mathrm{M} \mathrm{pH} \mathrm{8.0} \mathrm{EDTA,}$ and the last one with TBE $0.5 \mathrm{X}$ running buffer. After the last washing, the plugs were stored in the same TBE $0.5 \mathrm{X}$ running buffer at $4^{\circ} \mathrm{C}$. The samples of integral yeast DNA were applied in $1 \%$ agarose gel and sealed with same agarose. The gel was transferred into the CHEF-DR II (Bio Rad) Apparatus chamber, containing TBE $0.5 \mathrm{X}$ buffer, previously cooled at $14^{\circ} \mathrm{C}$ (14).

The chromosomal DNA separation run was carried out within 23 hours, at $200 \mathrm{~V}$ and at $14^{\circ} \mathrm{C}$, the first 15 hours with 60 -second pulses, and the remaining eight hours with 90 -second pulses (15). At the end of the run, the gel was stained with ethidium bromide (10 $\mu \mathrm{l} / \mathrm{ml}$ ) for approximately 30 minutes and observed and photographed (Polaroid 6FP 67 or Fuji FP 699 film) in UV transilluminator. The chromosomal bands molecular weight of the strains studied and obtained was estimated by the diagram drawn by employing the molecular weight $\log (\mathrm{Mb})$ of the Saccharomyces cerevisiae pattern against the gel migration distance (cm).

Random Amplified Polymorphic DNA (RAPD): amplifications were conducted in a total volume of $25 \mu \mathrm{l}$ containing $20 \mathrm{mM}$ Tris- $\mathrm{HCl}, \mathrm{pH} 8.4$, $4.50 \mathrm{mM} \mathrm{KCl}, 3.75 \mathrm{mM} \mathrm{MgCl}, 100 \mu \mathrm{l}$ of each deoxynucleotide (d NTP's), $30 \mathrm{ng}$ primer oligonucleotide, $40 \mathrm{ng}$ DNA and 1.5 U Taq DNA Polimerase (6). The experiment was conducted with OPB-12 and OPX-10 primers.

Pre-denaturation was conducted at $92^{\circ} \mathrm{C}$ for 2 minutes followed by 401 -minute cycles at $92^{\circ} \mathrm{C}, 1$ minute at $37^{\circ} \mathrm{C}$ and 2 minutes at $72^{\circ} \mathrm{C}$, total time of 3 minutes at $72^{\circ} \mathrm{C}$ in $\mathrm{MJ}$ Research Inc. PTC- $100^{\mathrm{TM}}$ thermocycler.

The products amplified were electrophoretically separated, in $1.3 \%$ agarose gel at $2.9 \mathrm{~V} / \mathrm{cm}$, for approximately 3 hours and 30 minutes. Lambda DNA cleaved with Hind III restriction enzyme was utilized as molecular weight marker. The gel was stained in ethidium bromide solution for 30 minutes and destained in water for further observation and photography (Polaroid 6FP 67 or Fuji FP 699 film) in UV transilluminator, with orange filter.

Yeast DNA Isolation for RAPD: isolation was conducted according to Johnston et al. (11), with the 
exception of not utilising RNAse. DNA samples were quantified by spectrophotometer (BECKMAN DU 640 [ $\lambda 260]$ ) and DNA integrity was analysed by DNA electrophoresis in $0.8 \%$ agarose gel for $1 \frac{1}{2}$ hour at $50 \mathrm{~V}$. Following electrophoresis, gel was stained in ethidium bromide and observed in UV transilluminator.

Dendrograms: the data obtained by RAPD were analysed by NTSYS-PC (Applied Biostatistics, Inc.). This program produced a similarity matrix by means of a coefficient of similarity, and a dendrogram was devised based on the analysis of the matrices by the UPGMA SAHN-clustering method. This dendrogram grouped the strains showing the level of similarity among each other.

\section{RESULTS AND DISCUSSION}

Pulsed-field yeast chromosomal DNA separation: in order to verify the taxonomic relationship of parental strains submitted to protoplast fusion and to analyse fusion products and recombinants obtained, yeast was submitted to electrophoretic karyotyping.

Table 1 shows flocculation and $\mathrm{H}_{2} \mathrm{~S}$ production, characteristic of parental strains ABXR.11B and IZ 987, fusion products FP 67 and FP 70, and segregants S26, S15 and S18 obtained from them.

Table 1: Characteristics of strains selected for electrophoretic karyotyping and RAPD.

\begin{tabular}{cccc}
\hline Strain & Remark & Flocculent & $\mathrm{H}_{2}$ S Production \\
\hline ABXR.11B & Parental Strain 1 & + & + \\
IZ 987 & Parental Strain 2 & - & - \\
FP 67 & Fusion Product & + & - \\
FP 70 & Fusion Product & - & + \\
S26 & Segregant & + & - \\
S15 & Segregant & - & - \\
S18 & Segregant & + & $+/-$ \\
\hline
\end{tabular}

$(+)$ indicates presence of the studied character;

(-) indicates absence of the studied character.

Individualized bands do not necessarily represent a chromosome since chromosomes with same or close molecular weight can be contained in the same band. Thus, the term chromosomal band was used to designate the bands visualised. The electrophoretic patterns of parental strains ABXR.11B and IZ 987, fusion products FP 67 and FP 70, and segregants S26,
S15 and S18 are shown in Fig. 1. Fig. 2 shows the schematic representation of the electrophoretic pattern of each strain. Table 2 contains the molecular weight of: parental strains ABXR.11B and IZ 987, fusion product FP 67 and segregant S15, obtained from the molecular weights of the pattern utilised $(S$. cerevisiae).

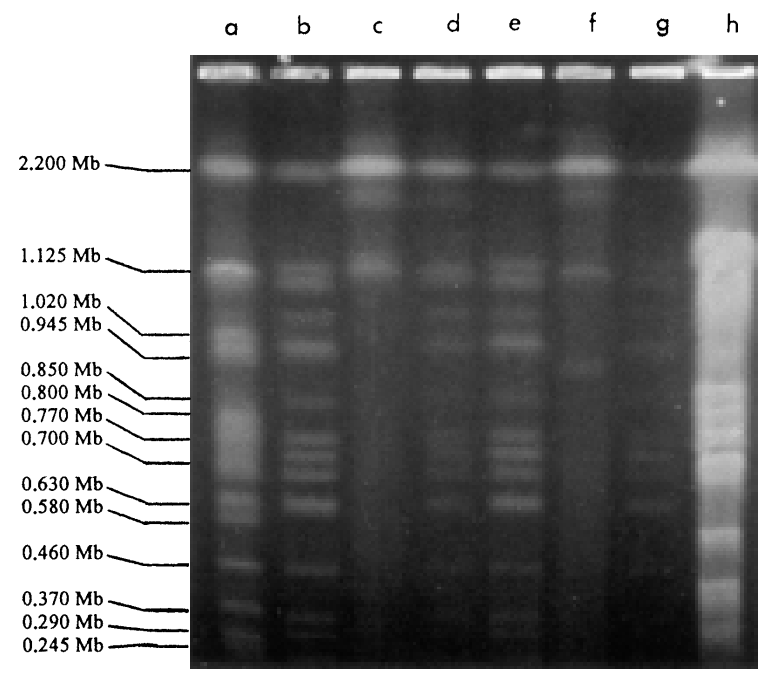

Figure 1: Chromosomal bands resolution of parental strains, of fusion products and of segregants. (a) Saccharomyces cerevisiae pattern; (b) ABXR.11B; (c) IZ 987; (d) FP 67; (e) S26; (f) S15; (g) S18; (h) FP 70

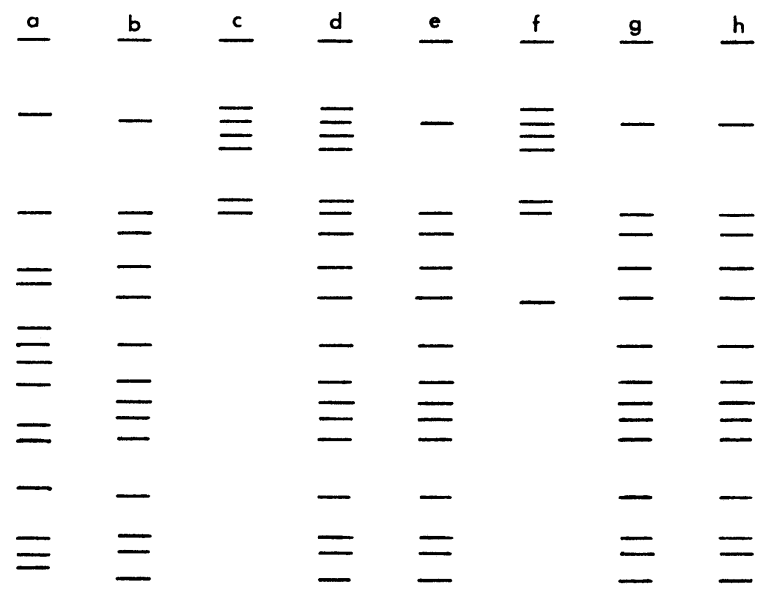

Figure 2: Diagram of the chromosomal bands resolution of parental strains, of fusion products and of segregants. (a) Saccharomyces cerevisiae pattern; (b) ABXR.11B; (c) IZ 987; (d) FP 67; (e) S26; (f) S15; (g) S18; (h) FP 70. 
It can be observed that the electrophoretic patterns of parental strains are very different, strain IZ 987 showed only 6 chromosomal bands ranging from 2.3 to $1.125 \mathrm{Mb}$, while strain ABXR.11B showed 14 chromosomal bands ranging from 2.09 to $0.215 \mathrm{Mb}$. Parental strain IZ 987 shows 2 chromosomal bands of molecular weight similar to parental strain ABXR.11B (2.09 to $0.215 \mathrm{Mb}$ ), band $1.125 \mathrm{Mb}$ is also present in $S$. cerevisiae pattern. Parental strain IZ 987 still shows the first chromosomal band with molecular weight very close to the first band of the pattern. Besides that, it can be observed that the resolution pattern of chromosomal bands of parental strain ABXR.11B is similar to the $S$. cerevisiae pattern.

By studying the data of chromosomal DNA separation of several yeast species analysed by the OFAGE Apparatus and obtained by Jonge et al. (12), a great difference in the band patterns among the different genera and species is observed. In addition, a difference in the electrophoretic pattern among strains of same species, but with a similar number and positioning of bands, can be observed.

Johnston and Mortimer (10), by using the OFAGE
Apparatus, found variations in the electrophoretic karyotyping of several strains of commercially- and scientifically-used Saccharomyces, as well as in strains of other species. The most interesting observation was the presence of only three chromosomal bands in Saccharomyces kluyveri, against 14 in Saccharomyces carlsbergensis, 14 in Saccharomyces uvarum and 17 in Saccharomyces bayanus. Based on these results, the authors suggested a reclassification of Saccharomyces kluyveri as another genus. These authors still detected that the species Candida albicans, Candida utilis, Kluyveromyces lactis, Pichia (Hansenula) canadensis and Schwanniomyces occidentalis have a small number of chromosomes, all of them larger than $1000 \mathrm{~kb}$.

Naumov et al. (15), investigating the genetic homology of 3 species akin to the Saccharomyces stricto senso genus by means of electrophoretic karyotyping, concluded that the 3 species analysed had 16 chromosomes, and that the electrophoretic karyotype of $S$. cerevisiae and $S$. paradoxus wild strains are practically identical, while the $S$. bayanus strains have species-specific karyotypes.

Table 2: Molecular weight of parental strains ABXR.11B and IZ 987, of fusion product FP 67 and of segregant S15.

\begin{tabular}{|c|c|c|c|c|c|c|c|c|c|c|}
\hline \multirow{2}{*}{$\begin{array}{c}\text { Band } \\
\#\end{array}$} & \multicolumn{2}{|c|}{$\begin{array}{l}\text { S. cerevisiae } \\
\text { pattern }\end{array}$} & \multicolumn{2}{|c|}{ ABXR.11B } & \multicolumn{2}{|c|}{ IZ 987} & \multicolumn{2}{|c|}{ FP 67} & \multicolumn{2}{|c|}{ S15 } \\
\hline & $\begin{array}{l}\text { Molec. } \\
\text { Weight } \\
(\mathrm{Mb})\end{array}$ & $\begin{array}{c}\mathrm{Rf} \\
(\mathrm{cm})\end{array}$ & $\begin{array}{l}\text { Molec. } \\
\text { Weight } \\
(\mathrm{Mb})\end{array}$ & $\begin{array}{c}\mathrm{Rf} \\
(\mathrm{cm})\end{array}$ & $\begin{array}{l}\text { Molec. } \\
\text { Weight } \\
(\mathrm{Mb})\end{array}$ & $\begin{array}{c}\mathrm{Rf} \\
(\mathrm{cm})\end{array}$ & $\begin{array}{l}\text { Molec. } \\
\text { Weight } \\
(\mathrm{Mb})\end{array}$ & $\begin{array}{c}\mathrm{Rf} \\
(\mathrm{cm})\end{array}$ & $\begin{array}{l}\text { Molec. } \\
\text { Weight } \\
(\mathrm{Mb})\end{array}$ & $\begin{array}{c}\mathrm{Rf} \\
(\mathrm{cm})\end{array}$ \\
\hline 1 & 2.200 & 1.15 & 2.090 & 1.25 & 2.300 & 1.05 & 2.300 & 1.05 & 2.300 & 1.05 \\
\hline 2 & 1.125 & 2.60 & 1.125 & 2.60 & 2.090 & 1.25 & 2.090 & 1.25 & 2.090 & 1.25 \\
\hline 3 & 1.020 & 3.45 & 1.090 & 2.90 & 1.900 & 1.45 & 1.900 & 1.45 & 1.900 & 1.45 \\
\hline 4 & 0.945 & 3.65 & 1.050 & 3.40 & 1.750 & 1.65 & 1.750 & 1.65 & 1.750 & 1.65 \\
\hline 5 & 0.850 & 4.30 & 0.940 & 3.85 & 1.250 & 2.40 & 1.250 & 2.40 & 1.250 & 2.40 \\
\hline 6 & 0.800 & 4.55 & 0.800 & 4.55 & 1.125 & 2.60 & 1.125 & 2.60 & 1.125 & 2.60 \\
\hline 7 & 0.770 & 4.80 & 0.710 & 5.10 & - & - & 1.090 & 2.90 & 0.930 & 3.90 \\
\hline 8 & 0.700 & 5.15 & 0.680 & 5.40 & - & - & 1.050 & 3.40 & - & - \\
\hline 9 & 0.630 & 5.75 & 0.670 & 5.65 & - & - & 0.940 & 3.85 & - & - \\
\hline 10 & 0.580 & 6.00 & 0.600 & 5.95 & - & - & 0.800 & 4.55 & - & - \\
\hline 11 & 0.460 & 6.70 & 0.450 & 6.80 & - & - & 0.710 & 5.10 & - & - \\
\hline 12 & 0.370 & 7.45 & 0.375 & 7.40 & - & - & 0.680 & 5.40 & - & - \\
\hline 13 & 0.290 & 7.70 & 0.310 & 7.65 & - & - & 0.670 & 5.65 & - & - \\
\hline 14 & 0.245 & 7.90 & 0.215 & 8.05 & - & - & 0.600 & 5.95 & - & - \\
\hline 15 & - & - & - & - & - & - & 0.450 & 6.80 & - & - \\
\hline 16 & - & - & - & - & - & - & 0.375 & 7.40 & - & - \\
\hline 17 & - & - & - & - & - & - & 0.310 & 7.65 & - & - \\
\hline 18 & - & - & - & - & - & - & 0.215 & 8.05 & - & - \\
\hline
\end{tabular}


The results above possibly indicate that the differences in band patterns obtained through chromosomal DNA separation in strains ABXR.11B and IZ 987 are due to a great taxonomic distance among these strains, strain ABXR.11B electrophoretic karyotype is similar to the Saccharomyces cerevisiae, while the strain IZ 987 karyotype suggests another genus. This fact may explain the high instability of fusion products obtained from it.

Moreover, fusion product FP 67 shows chromosomal band complementarily, while segregants (S26 and S18) of a fusion product show the same pattern of parental strain ABXR.11B. In contrast, segregant $\mathrm{S} 26$ shows the characteristic $\mathrm{H}_{2} \mathrm{~S}$ and segregant S18 shows an intermediary phenotype as to the $\mathrm{H}_{2} \mathrm{~S}$ production (low $\mathrm{H}_{2} \mathrm{~S}$ production). On the other hand, segregant S15 shows a chromosomal DNA separation intermediary pattern, with all bands of parental strain IZ 987, plus a band with molecular weight $(0.930 \mathrm{Mb})$ different from parental strain ABXR.11B.

The band with molecular weight $0.930 \mathrm{Mb}$ that appears in segregant S15 may have resulted from the loss of a patch of chromosome during mitotic permutation between the fusioned nuclei. Heluane et al. (8), separating hybrid chromosomes obtained through protoplast fusion between Pachysolen tannophilus and Saccharomyces cerevisiae, detected that the fusion products showed altered genomes compared to parental strains. This change was detected by the presence of 4 bands as in the first parental strains, but with mobility of 3 bands larger than the referred to parental strain.

Random Amplified Polymorphic DNA (RAPD): for such reaction, DNA from the strains specified in Table 1 was isolated. By utilizing two primers, an amplification pattern of DNA fragments for the strains under investigation was obtained, as demonstrated in Fig. 3. The two selected primers produced 11 polymorphic bands, and the combined analysis of these primers allowed the construction of a similarity matrix which prompted a dendrogram of genetic similarity among parental strains, fusion products and some segregants (Fig. 4).

Based on these data (Fig. 3), fusion product FP 67 is believed to be a hybrid, for it shows a pattern of complementary bands between parental strains. This kind of result was obtained by Francis and Clair (3), who conducted the progenesis identification of Pythium ultimun strain crossings. These authors, who also identified the $\mathrm{F}_{1}$ hydrides through band
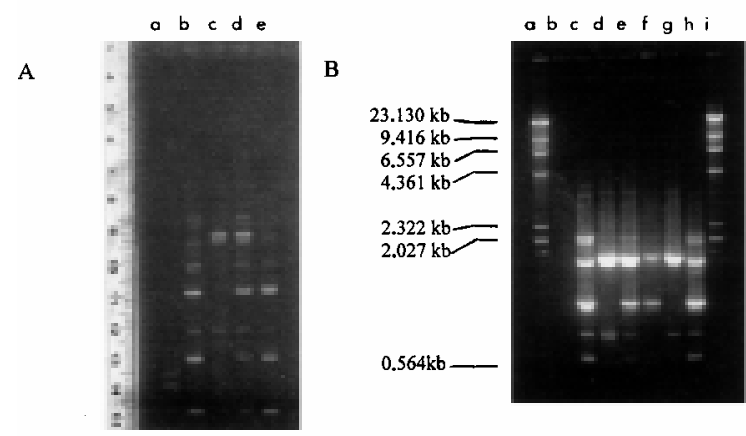

Figure 3: Amplification pattern of DNA fragments. (A) OPB-12, clockwise: ABXR.11R, IZ 987, FP 67, FP 70; (B) OPX-10, clockwise: molecular weight marker, blank, ABXR.11B, IZ 987, FP 67, S18, S15, FP 70, molecular weight marker.

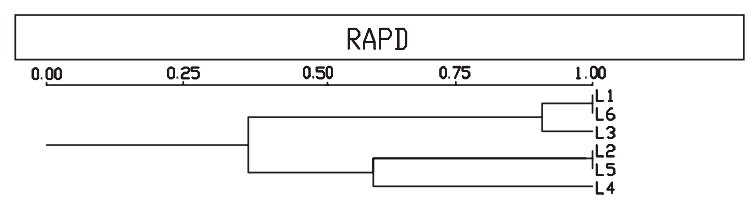

Figure 4: Dendrogram obtained from the genetic similarity matrix among parental strains, their fusion products and their segregants, based on data obtained through RAPD, where L1 stands for parental strain ABXR.11B; L2 for IZ 987; L3 for FP 67; L4 for segregant S18; L5 for segregant S15, and L6 for FP 70.

complementation, obtained a well-defined band in each parental strain, and the hydrides showed both bands. It can be verified that FP 70 shows an amplification pattern identical to parental strain ABXR.11B. However, when viewed through the amplification pattern obtained from OPX-10 primer (Fig. 3B), it can be verified that the strain S15 is similar to parental strain IZ 987 and segregant S18 shows a new pattern.

Gomes (5), by comparing yeast identification methods, detected that RAPD is the most sensitive and most efficient method in identifying very similar strains, which show a high similarity coefficient. Based on these findings, we can suggest that the low similarity coefficient observed among parental strains leads to a large genetic divergence among them, emphasising the hypothesis that the strain does not belong to the Saccharomyces genus.

\section{CONCLUSIONS}

Based the results of this study, we can conclude that: (a) protoplast fusion was efficient in obtaining 
new genotypes from taxonomically distant strains, as observed in strains ABXR.11B and IZ 987; (b) strain IZ 987 may not belong to the Saccharomyces genus, as having an electrophoretic karyotype profile very different from all karyotypes obtained and presented by the literature about this genus. The low similarity coefficient viewed in the dendrogram obtained from RAPD data also leads to this fact.

In conclusion, we suggest that the recombinant strains obtained in this study, which present high flocculation and $\mathrm{H}_{2} \mathrm{~S}$ non-production, should be analysed as to their both technological and industrial viability.

\section{RESUMO}

\section{Caracterização de produtos de fusão de protoplastos de leveduras e seus segregantes via cariotipagem eletrodorética e RAPD}

Com o objetivo de caracterizar os produtos de fusão de protoplastos de leveduras com características de importância para a indústria vinícola e seus segregantes, foram empregadas as técnicas de separação de bandas cromossômicas por eletroforese e de RAPD (amplificação ao acaso de DNA polimórfico). O cariótipo eletroforético foi realizado pelo método CHEF ("contour-clamped homogeneous eletric field eletrophoresis"), constatando-se a complementação de bandas cromossômicas no produto de fusão e padrões de ambos os parentais e padrões intermediários nos segregantes. A análise do padrão de amplificação dos fragmentos de DNA com dois primers evidenciou um padrão de bandas complementares nos produtos de fusão (diplóide) e padrão de bandas de um e de outro parental ou mesmo bandas intermediárias nos segregantes.

Palavras-chave: fusão de protoplastos, cariótipo eletroforético, RAPD.

\section{REFERENCES}

1. Bellis, M.; Pagès, M.; Roizès, G. A simple and rapid method for preparing yeast chromosomes for Pulse Field Gel Electrophoresis. Nucl. Acids Res., 15, 6749, 1987.
2. Degré, R.; Thomas, D.Y.; Ash, J.; Mailhiot, K.; Morin, A.; Dubord, C. Wine yeasts strain identification. Am. J. Enol. Vitic., 40, 309-315, 1989.

3. Francis, D.M.; Clair, D.A. St. Outcrossing in the homothallic oomycete, Pythium ultimatum, detected with molecular markers. Curr. Genet., 24, 100-106, 1993.

4. Frezier, V.; Dubourdieu, D. Ecology of yeast strain Saccharomyces cerevisiae during spontaneous fermentation in a Bordeaux winery. Am. J. Enol. Vitic., 43, 375-380, 1992.

5. Gomes, L.H. Avaliação de quatro métodos para a identificação de leveduras. Piracicaba, 1995. 88 p. (Dissertação Mestrado. Escola Superior de Agricultura "Luiz de Queiroz"/USP).

6. Gomes, L.H.; Argueso, J.L.; Duarte, K.M.R.; Tavares, F.C.A. $R A P D$ para identificação leveduras industriais. In: Reunião anual de genética de microrganismos, 20, Piracicaba, 1995. Anais. Piracicaba: ESALQ-Depto. de Genética, 1995. p.154.

7. Hammond, J.R.M. Brewer's yeasts. In: Rose, A.H.; Harrison, J.S. (eds). The Yeasts. Academic Press, London, 1993. v.5, p.7-67.

8. Heluane, H.; Spencer, J.F.T.; Spencer, D.; Figueroa, L. de; Callieri, D.A.S. Characterization of hybrids obtained by protoplast fusion, between Pachysolen tannophilus and Saccharomyces cerevisiae. Appl. Microbiol. Biotechnol., 40, 98-100, 1993.

9. Ibeas, J.I.; Jimenez, J. Electrophoretics karyotype of budding yeasts with intact cell wall. Nucl. Acids Res., 21, 3902, 1993.

10. Johnston, J.R.; Mortimer, R.K. Electrophoresis karyotyping of laboratory and commercial strains of Saccharomyces and other yeasts. Int. J. Syst. Bacteriol., 36, 569-572, 1986.

11. Johnston, J.R.; Contopoulou, C.R.; Mortimer, R.K. Karyotyping of yeast strains of several genera by field inversion gel electrophoresis. Yeast, 4, 191-198, 1988.

12. Jonge, P.; Jongh, F.C.M. de; Meijers, R.; Steensma, H.Y.; Scheffers, W.A. Orthogonal-field-alternation gel electrophoresis banding patterns of DNA from yeasts. Yeast, 2, 193-204, 1986.

13. Kunkee, R.E.; Bisson, L.F. Wine-making yeasts. In: Rose, A.H.; Harrison, J.S. (Ed.) The Yeasts: Yeast technology. Academic Press, London, 1993. v.5, p.69-127.

14. McCluskey, K.; Russel, B.W.; Mills, D. Electrophoretic karyotyping without the need for generating protoplasts. Curr. Genet, 18, 385-386, 1990.

15. Naumov, G.; Naumova, E.S.; Lantto, R.A.; Louis, E.J.; Korhola, M. Genetic homology between Saccharomyces cerevisiae and its sibling species $S$. paradoxus and $S$. bayanus: electrophoretic karyotypes. Yeast, 8, 599-612, 1992.

16. Parish, M.E.; Carrol, D.E. Fermentation characteristics of Saccharomyces cerevisiae isolates from Vitis rotundifolia grapes and musts. Am. J. Enol. Vitic., 38, 45-8, 1987.

17. Rose, A. H.; Harrison, J. S. Introduction. In: Rose, A. H.; Harrison, J. S. (eds) The Yeasts: Yeast technology. Academic Press, London, 1993. v.5, p.1-6.

18. Sheehan, C. A.; Weiss, A. S.; Newsom, I. A.; Flint, V.; O’Donnel, C. D. Brewing yeast identification and chromosome analysis using high resolution CHEF gel electrophoresis. J. Inst. Brew., 97, 163-167, 1991.

19. Varnam, A. H.; Sutherland, J. P. Beverages: Technology, chemistry and microbiology. Chapman \& Hall, London, 1994. $464 \mathrm{p}$.

20. Vezinhet, F.; Blondin, B.; Hallet, J-N. Chromosomal DNA patterns and mitochondrial DNA polymorphism as tools for identification of enological strains of Saccharomyces cerevisiae. Appl. Microbiol. Biotechnol.,.32, 568-571, 1990.

21. Vine, R. P. Applications of technology in wine production. In: Gump, B. H. Beer and wine production; analysis, characterization and technological advances. American Chemical Society, Washington, 1993, p.132-49. 